\title{
SPRAWOZDANIE Z XI MIĘDZYNARODOWEGO KONGRESU JÓZEFOLOGICZNEGO W CIUDAD GUZMAN W MEKSYKU
}

DOI: http://dx.doi.org/10.12775/TiCz.2014.010

W dniach od 30 września do 6 października 2013 roku w Ciudad Guzman w Meksyku odbył się XI Międzynarodowy Kongres Józefologiczny pod hasłem: „Święty Józef obrońca życia i miłości”. Zanim przejdziemy do omówienia ważniejszych treści poruszonych podczas sympozjum, warto na chwilę zatrzymać się nad meksykańską pobożnością związaną z osobą św. Józefa, a zwłaszcza z historią miasta, któremu powierzona została organizacja obrad.

\section{NABOŻEŃSTWO DO ŚW. JÓZEFA}

Cały Meksyk jest naznaczony szczególną czcią dla św. Józefa. Jak pisze choćby ojciec Carlos Carillo Ojeda w swojej książce Presencia de San José en México, już pierwsi ewangelizatorzy Meksyku często uciekali się pod opiekę św. Józefa. Słynny misjonarz Antoni z Segowii nadał nazwę

${ }^{*}$ Ks. Andrzej Antonii Klimek jest prezbiterem diecezji kaliskiej i redaktorem naczelnym „Opiekuna” 
Święty Józef z Analco miejscowości (dzisiaj część Guadalajary), w której gromadził i nawracał tubylców, wznosząc tam również kaplicę ku czci Patriarchy z Nazaretu już w 1543 roku. W roku 1555 Pierwszy Synod Prowincjalny w Meksyku ogłosił św. Józefa patronem młodego Kościoła, doceniając wielkie nabożeństwo, tak tubylców, jak i Hiszpanów, którzy widzieli w Józefie obrońcę od burz, grzmotów i gradu, często nękających tę ziemię. Ustanowiono dzień 19 marca świętem i właśnie w tym dniu w roku 1682 roku zdarzyło się trzęsienie ziemi, które zapisuje się w historii jako „Wstrząsy św. Józefa”. Archidiecezja Meksyk ogłosiła św. Józefa patronem od trzęsień ziemi. Wstrząsy powtórzyły się w marcu 1729 roku i wówczas również władze miasta poprosiły arcybiskupa Meksyku, by ogłosić św. Józefa szczególnym patronem i obrońcą przed tym żywiołem. Arcybiskup 28 grudnia 1731 roku oficjalnie zaakceptował petycję władz. I tak rozszerza się kult św. Józefa, zwłaszcza jako obrońcy od trzęsień ziemi, a najlepszym tego przykładem jest miasto Ciudad Guzmán.

\section{SANKTUARIUM ŚW. JÓZEFA W CIUDAD GUZMÁN}

Zapotlán el Grande, jak niegdyś nazywało się Ciudad Guzmán (dla większości mieszkańców w dalszym ciągu istnieje tylko stara nazwa), od 1747 roku oddaje szczególną cześć św. Józefowi, bo też i trzęsienia ziemi zdarzają się tutaj wyjątkowo często. Na głównym placu miasta, tuż przed fasadą katedry - sanktuarium, znajduje się tablica świetlna informująca o stanie zagrożenia sejsmicznego. Stan alertu jest tu praktycznie permanentny. Kiedy człowiek widzi żółte światło alertu, niemal odruchowo wchodzi do katedry i modli się, oddając cześć Maryi i św. Józefowi reprezentowanym $\mathrm{w}$ figurach stojących po obu stronach prezbiterium.

Nie wiemy dokładnie, skąd wzięły się figurki Maryi i Józefa z Dzieciątkiem, ale jak głosi tradycja, pewnego dnia zatrzymał się w karczmie Cofradía del Rosario (czyli konfraternia Różańcowa miała swoją karczmę) przy królewskiej drodze Colima nieznajomy prowadzący mulicę, obładowaną dwiema skrzyniami. Następnego dnia zniknął, pozostawiając tajemnicze skrzynie. Gdy mieszkańcy zdecydowali się je otworzyć, ujrzeli piękne figury św. Józefa i Dziewicy Maryi, a proboszcz - -ojciec Jan Antonio Caro stwierdził, że ponieważ nikt nie domaga się ich zwrotu, należy przenieść je do parafii, co też w procesji uczyniono. W ten sposób do patronatu Najświętszej Maryi Panny Wniebowziętej, który datował się od założenia miasta w 1533 roku, Zapotlán el Grande 
oddało się również w 1747 roku pod szczególną opiekę św. Józefa. Dwa lata później, po kolejnym trzęsieniu ziemi 22 października 1749 roku, mieszkańcy złożyli 29 grudnia tego samego roku uroczyste ślubowanie, w którym zobowiązali się do obchodzenia corocznego święta ku czci św. Józefa 22 października i, jak to ujął miejscowy poeta, od tego czasu „Św. Józef należy do Zapotlán, a lud Zapotlán do św. Józefa".

W połowie XX wieku mieszkańcy miasta podjęli starania o koronację papieską i pod koniec roku 1956 ich działania doczekały się konkretyzacji. Ówczesny arcybiskup Guadalajary, Józef Garibi Rivera, zwrócił się z prośbą do Stolicy Apostolskiej, która udzieliła zgody w następujących słowach: „Z przyjemnością wychodzimy naprzeciw tym pragnieniom poprzez niniejszy list i zezwalając naszą powagą Apostolską, wyznaczamy arcybiskupa Guadalajary, by ukoronował złotą koroną, w naszym imieniu, wizerunek św. Józefa, czczony z nabożeństwem w kościele parafialnym w Zapotlán el Grande". Uroczystość koronacji wszystkich trzech figur Świętej Rodziny odbyła się 22 października 1957 roku.

Na szczególną wzmiankę zasługuje sposób świętowania mieszkańców Ciudad Guzman, bo tak jak świętują Meksykanie, chyba nikt nie potrafi. Świętuje się praktycznie już od ostatnich dni sierpnia aż do końca października. Podczas jednego zaledwie tygodnia na przełomie września i października uczestnicy Kongresu wzięli udział w dwóch wielkich procesjach ku czci Patrona, które były zaledwie zapowiedzią głównych uroczystości, jakie zgodnie ze ślubowaniem przodków odbywają się 22 i 23 października.

\section{PIERWSZY DZIEŃ KONGRESU}

Pierwszym oficjalnym wydarzeniem Kongresu była krótka wycieczka turystyczna zaproponowana przez władze miejskie Ciudad Guzman (miasto ponad stutysięczne, od niedawna siedziba diecezji), która została zwieńczona uroczystym posiedzeniem Rady Miejskiej z udziałem gości kongresowych. Władze miasta nadały uczestnikom status specjalnych gości, witając każdego z osobna i ofiarowując pamiątkowy album oraz certyfikat. Uroczysta sesja rady zakończyła się obiadem ufundowanym przez władze miejskie.

Najważniejszą częścią dnia była wyżej wspomniana wielka kolorowa i głośna procesja ku czci św. Józefa związana z zapowiedzią 
wielkiego święta Patrona, które obchodzono 22 i 23 października. 33 grupy tancerzy $\mathrm{z}$ różnych grup pobożnościowych zaprezentowały się w paradzie, której nie przeszkodził nawet ulewny deszcz. O godzinie 19.00 uroczysta msza święta celebrowana przez Ordynariusza miejsca i wszystkich kapłanów w katedrze, która jest jednocześnie sanktuarium św. Józefa, zainaugurowała XI Międzynarodowy Kongres Józefologiczny. Ostatnim aktem dnia było poświęcenie figury Świętego Józefa obrońcy życia i miłości, która stanęła na terenie seminarium diecezjalnego, gdzie odbywały się obrady kongresowe.

Polska była reprezentowana na Kongresie przez następujące osoby: ks. prof. Krzysztofa Koneckiego z Uniwersytetu Mikołaja Kopernika z Torunia, ks. dra hab. Dariusza Kwiatkowskiego z UAM w Poznaniu, ks. dra Andrzeja Latonia, prezesa Polskiego Studium Józefologicznego, ks. Ignacio Solera, Hiszpana od lat pracującego w warszawskiej prałaturze Opus Dei, ks. Andrzeja Antoniego Klimka, redaktora naczelnego Dwutygodnika Diecezji Kaliskiej „Opiekun” i siostrę Dolores Siutę CSSJ ze zgromadzenia Sióstr Świętego Józefa, którzy przedstawili referaty podczas Kongresu. W polskiej delegacji byli również obecni: ks dr Jacek Plota, kustosz sanktuarium św. Józefa w Kaliszu, ks. Paweł Kostrzewa z diecezji kaliskiej i ojciec Benedykt Belgrau, karmelita bosy z Wadowic. Wspomnijmy jeszcze ks. Ryszarda Dyca, Polaka pracującego w Manheim i reprezentującego na Kongresie niemieckie środowisko józefologiczne, który również wygłosił prelekcję.

W niniejszym opracowaniu nie stawiamy sobie za cel zreferowania wszystkich czterdziestu prelekcji wygłoszonych podczas XI Międzynarodowego Kongresu Józefologicznego w Meksyku, a jedynie zasygnalizowanie najciekawszych wystąpień ze szczególnym uwzględnieniem prelegentów z Polski, z nadzieją oddania przekroju tematycznego i bogactwa poruszanych argumentów.

\section{ŚWIĘTY JÓZEF W NAUCZANIU PASTERSKIM}

Drugi dzień Kongresu był de facto pierwszym dniem obrad, podczas którego zostało przedstawionych osiem prelekcji: cztery $\mathrm{w}$ sesji porannej i cztery w sesji poobiedniej. Taki też był porządek wszystkich kolejnych dni kongresowych. W sesji porannej wystąpił m.in. ks. Ryszard Dyc z Manheim, który przedstawił konferencję na temat św. Józefa robotnika Winnicy Pańskiej na przykładzie pism św. Edyty Stein. 
Natomiast sesję popołudniową rozpoczął ks. prof. Dariusz Kwiatkowski przedłożeniem na temat „Św. Józef jako obrońca rodzin i patron życia poczętego w nauczaniu Stanisława Napierały, pierwszego biskupa diecezji kaliskiej", któremu poświęcimy więcej miejsca. Ks. Kwiatkowski przypomniał najważniejsze linie przepowiadania ks. biskupa Stanisława: rodzina jako fundament Kościoła i społeczeństwa, Święta Rodzina wzorem dla rodzin chrześcijańskich, zagrożenia rodziny współczesnej i wreszcie obrona życia poczętego. Prelegent przypomniał, że rodzina stanowi fundamentalne dobro każdego człowieka, ponieważ w niej człowiek się rodzi i znajduje środowisko potrzebne do prawidłowego rozwoju i dojrzewania. $Z$ tego faktu można wyprowadzić stwierdzenie, że rodzina jest dobrem narodu i całej ludzkości. Prawdziwa rodzina jest zawsze wspólnotą osób: małżonków i dzieci przez nich zrodzonych. Ta wspólnota nie bierze się z ustanowienia ludzkiego, ale jest zakorzeniona w naturze człowieka stworzonego przez Boga, stworzonego jako mężczyzna i kobieta. Rodzina chrześcijańska jest środowiskiem, w którym, jak nauczał biskup Stanisław, urzeczywistnia się świętość Kościoła, bo też rodzina jest Kościołem, w którym rodzi się wiara i w którym człowiek może znaleźć motywację, by rozwijać w sobie cnoty, szlachetne postępowanie i usuwać wady. Modelem dla rodziny jest oczywiście Święta Rodzina, która cieszyła się obecnością w niej Jezusa i jednoczyła się w realizacji Bożego zbawczego planu.

Ks. Kwiatkowski przypomniał zagrożenia dla rodziny, o których często wspominał w swoim nauczaniu pierwszy Biskup Kaliski. W kontekście roli św. Józefa w zbawczych planach Bożych bardzo ostro rysuje się dzisiaj kryzys ojcostwa, łączący się w pewien sposób $\mathrm{z}$ frustracją mężczyzny, ojca i małżonka, który często czuje się niepotrzebny, a czasem wręcz przegrany. Zagrożeniem dla rodziny jest również niewłaściwe rozumienie jej istoty, roli oraz zadań, jakie ma do spełnienia. Ksiądz Kwiatkowski cytuje biskupa Napierałę, który przypomina, że dzisiaj często za rodzinę próbuje się uznawać związki, które nią nie są. Tłumaczy się to nową sytuacją i nowymi warunkami życia, proponując patologię małżeństwa i rodziny, bo tak trzeba nazwać wolne związki partnerskie lub związki homoseksualne. Jeszcze jednym zagrożeniem dla rodziny, które ks. Kwiatkowski dostrzegł w nauczaniu pierwszego Biskupa Kaliskiego, jest kwestia niewłaściwego świętowania niedzieli, która powinna być świętym czasem odpoczynku, bycia z rodziną, zamyślenia nad samym sobą i przede wszystkim spotkania z Bogiem na Eucharystii, a staje się dniem, jak każdy inny, przeznaczonym na pracę i zakupy. 
Prelegent zauważył, że temat rodziny w nauczaniu biskupa Napierały był ściśle związany z kwestią obrony życia od poczęcia aż do naturalnej śmierci. Biskup przypominał fundamentalną prawdę, która nie jest kwestionowana przez naukę, że życie człowieka zaczyna się w momencie poczęcia. Aborcja nie jest ani nowoczesnością, ani postępem, jest natomiast wyrafinowanym zabijaniem i barbarzyństwem. Biskup Napierała przypominał, że w zabójstwie aborcji uczestniczy wiele osób i instytucji: najpierw ci, którzy uchwalają prawo, a także ci, którzy w jakikolwiek sposób biorą w niej udział, czyli lekarze i osoby do aborcji namawiające. Kolejnym problemem związanym z obroną życia poczętego jest dyskusja wokół pozaustrojowego zapłodnienia in vitro, które w rażący sposób rozmija się z godnością, do jakiej ma prawo każdy poczęty człowiek.

Na zakończenie swojej prelekcji ksiądz Kwiatkowski podkreślił, że nauczanie biskupa o obronie życia jest ściśle powiązane z działaniem, czego przykładem jest choćby "okno życia” usytuowane w budynku klasztoru sióstr nazaretanek w Kaliszu, comiesięczne modlitwy w bazylice św. Józefa, czy petycje kierowane do odpowiednich władz. Wszystkie sprawy, o których napisano powyżej, w nauczaniu biskupa Stanisława Napierały są zawsze ściśle związane z powierzeniem ich opiece św. Józefa i wzorowaniu się na nim.

\section{ŚWIĘTY JÓZEF WYCHOWAWCĄ I OJCEM O SYNOWSKIM SERCU}

W drugim dniu obrad z sesji przedpołudniowej warte podkreślenia są dwie prelekcje. Autorem pierwszej był ojciec Angelo Catapano z Italii, którego przedłożenie było zatytułowane: „O ojcostwie wychowawczym. Św. Józef obrońca życia i miłości” i było bodaj najdłuższą konferencją całego Kongresu. Drugą konferencją, nad którą się zatrzymamy, było wystąpienie prezesa Polskiego Studium Józefologicznego ks dra Andrzeja Latonia „Święty Józef - Świadek misterium Życia i Miłości. Refleksje filozoficzno-teologiczne".

Ojciec Catapano rozpoczął swoje wystąpienie bardzo sugestywnym stwierdzeniem, mianowicie nazwał Świętego Józefa "otwartą bramą", której nie wolno przeoczyć ani zlekceważyć, jeśli chcemy wejść na ścieżkę wiary i nadal nią kroczyć. Wszystkie posługi winny więc być wzorowane na przykładzie św. Józefa, tak ojcostwo, jak kapłaństwo i biskupstwo. Prelegent zaznaczył, że wszelkie rozważania o Józefie powinny się koncentrować przede wszystkim na jego misji ojcowskiej. Reprezentuje on 
bowiem wszystkich ojców wszech czasów, wszystkich wychowawców, którzy chronią życie i wzrastanie swoich małych dzieci. Jak pisał Jan Paweł II w Redemptoris Custos Józef jest „naprawdę ojcem”.

Prelegent przypomniał, że Maryja i Józef uczynili swoją miłość do syna absolutnie ekskluzywną, miłością „na wyłączność” dla Syna Bożego, nie mogło być już miejsca na inne dzieci, a ich miłość małżeńską - miłością dziewiczą. Razem oddają się Bogu całkowicie, a słowa wypowiedziane później przez Jezusa o niektórych, którzy pozostają bezżenni dla królestwa Bożego tak trudne do zrozumienia dla wielu (por. Mt 19,7-12) postawią w zupełnie innym świetle ich wybór i relację. Według badań archeologicznych dom rodziców Maryi (dom Zwiastowania) był odległy zaledwie 500 metrów od domu Józefa (dom Wychowania), ale „Wzięcie do siebie Maryi” wymagało od Józefa wielkiego wysiłku i decyzji wręcz niezrozumiałej $\mathrm{w}$ środowisku żydowskim, która pozostaje wielką tajemnicą, misterium po dziś dzień. Józef i Maryja stają się w ten sposób „najpiękniejszą parą" historii, jak ich nazywa Benedykt XVI, który tłumaczy, że Bóg po wielkim zawodzie, jakim była para proto-rodziców, czyli pierwszych rodziców Adama i Ewy szukał nowej pary, która stałaby się dla Niego bramą do ponownego wejścia w świat i historię i znalazł ją w Małżonkach z Nazaretu.

Ojciec Catapano podkreślił również, że jeśli istnieje jakiś wzór osoby, która czyni wolą Bożą zawsze, natychmiast i z radością, to jest nią św. Józef. Prelegent zasugerował, że każdy wychowawca powinien uznać jako swój własny projekt na życie, jako powołanie wychowawcy właśnie to: uczynić wolę Bożą nieustanną busolą wskazującą kierunek własnej wędrówki. Po spełnieniu podstawowego obowiązku, jakim było uratowanie i chronienie życia Jezusa, Józef poświęca się obowiązkom wychowawczym. Prelegent po przedstawieniu różnych uwarunkowań zatrzymuje się również na epizodzie zagubienia się Jezusa podczas dorocznej pielgrzymki do świątyni w Jerozolimie. „Synu, czemuś nam to uczynił? Oto ojciec Twój i ja z bólem serca szukaliśmy Ciebie”. "Czemuście Mnie szukali? Czy nie wiedzieliście, że powinienem być w tym, co należy do mego Ojca?" (Łk 2, 48-49). Catapano zauważa, że w tym dialogu pozostającym misterium, to Maryja przedstawia stan swojego serca i serca jej małżonka, umieszczając jednak na pierwszym miejscu zmartwionego Józef, dla którego ten epizod był znacznie trudniejszy niż dla niej. Maryja dotrze z Jezusem aż do stóp krzyża i przeżyje to misterium, św. Józef nie. Dla Świętego Józefa trzy dni nieobecności Syna są udziałem $\mathrm{w}$ misterium śmierci i trzech dni $\mathrm{w}$ grobie przed 
zmartwychwstaniem. Święty Józef w pewien sposób antycypował misterium paschalne, które będzie nastąpi za 20 lat, kiedy św. Józefa już nie będzie pośród żywych. Jest to ważna lekcja dla Józefa, którą on na pewno przyjmuje. Od tego momentu jego rola będzie się zmniejszać, podczas gdy będzie wzrastał Syn Boży. Gdyby Józef nie zaczął systematycznie redukować swojej wychowawczej roli ojcowskiej, jak każdy ojciec i wychowawca powinien uczynić, jego Syn nie mógłby się w pełni zamanifestować.

Prelegent zgadza się ze stwierdzeniem, że o dalszych latach wychowywania Jezusa nie wiemy nic, ale zastanawia się, czy kiedy na przykład Jezus mówi: „Wszystko przekazał Mi Ojciec mój. Nikt też nie zna Syna, tylko Ojciec, ani Ojca nikt nie zna, tylko Syn i ten, komu Syn zechce objawić" (Mt 11,27), nie można tam czegoś odkryć o relacji między Józefem a Jezusem? Czy jest absolutnie rozdzielone w Jezusie to, co otrzymał od Ojca Niebieskiego od tego, czego się nauczył od Józefa? Zdaniem Catapano w wielu miejscach Ewangelii możemy dostrzec ślady działalności wychowawczej Józefa w nauczaniu Jezusa. Przywołuje on słowa Benedykta XVI, że "nie jest przesadą myślenie, że to właśnie od ojca Józefa przejął Jezus - w ludzkim wymiarze - solidną formację wewnętrzną, będącą punktem wyjścia dla autentycznej sprawiedliwości, którą później przekaże swoim uczniom", aby przypomnieć, że każdy rodzic, nauczyciel i wychowawca, zwłaszcza w dobie kryzysu wartości, w jakiej przyszło nam żyć, powinien brać przykład ze Świętego Józefa, który jest wzorcowym wychowawcą.

Ksiądz dr Andrzej Latoń w swojej filozoficzno-teologicznej refleksji, zwłaszcza w jej pierwszej części, postawił sobie za cel zgłębienie samej istoty "tajemnicy Józefa” w świetle myśli błogosławionego Jana Pawła II. Swoje rozważania rozpoczął od cytatu z Ewangelii, który Jan Paweł II uważał za moment centralny biblijnej prawdy o św. Józefie (RC2): „Józefie, synu Dawida, nie bój się wziąć do siebie Maryi, twej Małżonki; albowiem z Ducha Świętego jest to, co się w Niej poczęło. Porodzi Syna, któremu nadasz imię Jezus, On bowiem zbawi swój lud od jego grzechów" (Mt 1, 20-21). Papież pisze, że od chwili zwiastowania znalazł się Józef - wraz z Maryją - niejako wewnątrz tajemnicy "od wieków ukrytej w Bogu”, która przyoblekła się w ciało (RC15). Dla księdza Latonia stwierdzenie Papieża, że Józef znalazł się "we wnętrzu samej tajemnicy” jest fundamentalne dla józefologii i na tej podstawie chciał ukazać wyjątkowe miejsce św. Józefa w historii zbawienia. Stąd jego referat odnosił się do "tajemnicy Józefa”, i jego uczestnictwa w Tajemnicy Boga, który jest Życiem i Miłością. 
Rozważania tajemnicy prelegent oparł na refleksji francuskiego myśliciela Gabriela Marcela, który wprowadził istotne rozróżnienie pomiędzy „problemem” i "tajemnicą". Dla Marcela problem to coś, co znajduje się w całości przede mną i co mogę określić i ograniczyć. Tajemnica natomiast jest rzeczywistością, w którą ja sam jestem zaangażowany, w związku z czym rozróżnienie w tajemnicy tego, co jest we mnie, i tego, co jest przede mną, traci swoje znaczenie i swą wartość pierwotną. Do rozwiązania problemu można zastosować pewną technikę. Tajemnica wykracza poza wszelkie techniki. Tajemnica według Marcela, nie jest czymś niezrozumiałym, zakazanym czy irracjonalnym, jest natomiast związana ze światłem, czy może raczej wydziela pewne światło, „które nie jest światłem wiedzy, ale które sprzyja rozwojowi wiedzy, jak słońce umożliwia wzrost drzewa, lub rozwinięcie się kwiatu".

Ksiądz Latoń chce powiedzieć za Janem Pawłem II, że św. Józef jest depozytariuszem tajemnicy Boga, czyli świadkiem tajemnicy. Być świadkiem $\mathrm{w}$ najgłębszym sensie, i tu znowu przychodzi z pomocą Marcel, znaczy dać swoje życie na służbę, aby rzeczywistość mogła objawić się światu. Samo imię Józef mówi nam, że powołaniem Patriarchy z Nazaretu jest bycie świadkiem w tym sensie. Józef w języku hebrajskim znaczy „Bóg da więcej”. Jeżeli więc Jan Paweł II stwierdza, że św. Józef znajduje się w centrum tajemnicy, to chce powiedzieć, że udział św. Józefa w historii zbawienia, podobnie jak udział Maryi, jest konieczny, jedyny i wyjątkowy. Józef był sługą Życia, które się objawiło, bo sam był uczestnikiem życia, to znaczy był w prawdziwej relacji z Bogiem Ojcem.

Według księdza Latonia św. Józef ukazuje nam również to, czym każdy z nas powinien się stać: podobieństwem Ojca, bo tak zostaliśmy stworzeni. Chodzi o relację Ojciec - syn i o jej przywrócenie. Prelegent nazywa to relacją na sposób zrodzenia, która odróżnia człowieka od wszystkich innych stworzeń powołanych do życia przez Boga jako coś zewnętrznego. Tylko człowiek ma tchnienie Bożego Ducha. Stąd też największym cierpieniem człowieka jest zerwanie relacji z Ojcem, źródłem życia.

Biblia ukazuje Józefa jako syna, gdy nazywa go „sprawiedliwym”, to znaczy całkowicie posłusznym Ojcu. Być posłusznym oznacza mieć synowskie uczucia, tak samo jak Jezus Chrystus. Jeżeli więc o Maryi można powiedzieć, że była „Córką swojego Syna” to i Józef był „Synem swojego Syna". Dlatego też istota tajemnicy Świętego Józefa nie tkwi w często kontemplowanych ofiarności, dyspozycyjności i innych jego cnotach, ale w jego sercu. Ciekawym faktem filologicznym, ale i teologicznym jest to, że św. Mateusz, opisując „zbudzenie się ze snu” św. Józefa, po którym nastąpiło wzięcie do siebie brzemiennej Maryi, używa tego samego czasownika, 
którym później określi zmartwychwstanie Jezusa. Ks. Latoń twierdzi, że Józef w swoim zwiastowaniu otrzymał odmienny stan egzystencji. To nie był zwykły sen, ale doświadczenie odkupienia z grzechu pierworodnego, przezwyciężenie śmierci grzechu. Ten sen był proroczą zapowiedzią zmartwychwstania Chrystusa, ale i udziałem w tym zmartwychwstaniu. Tak „wyposażony” Józef, stwierdził ks. Latoń, z takim synowskim sercem, był najlepszym powiernikiem i obrońcą Bożych skarbów.

\section{ŚWIĘTY JÓZEF I JEGO NIEOBECNA OBECNOŚĆ W LITURGIl}

Najciekawszym wystąpieniem w czwartym dniu Kongresu i trzecim dniu obrad był wykład ks. profesora dra hab. Krzysztofa Koneckiego, który zaskoczył wszystkich uczestników Kongresu tytułem swojej prelekcji: „Nieobecna obecność św. Józefa w liturgii” i od samego początku, nie ukrywał, że była to celowa prowokacja. Nie chodziło mu bynajmniej o postulowanie tworzenia nowych świąt, czy wspomnień dotyczących św. Józefa w kalendarzu liturgicznym, co byłoby niezgodne z reformą liturgiczną i niepotrzebne, ale o „odsłonięcie" i „wydobycie z cienia” osoby św. Józefa w tych tajemnicach życia Jezusa, w których musiał uczestniczyć jako domniemany ojciec, a które na sposób sakramentalny są uobecniane w liturgicznym „dziś" Kościoła.

Zanim ksiądz Konecki przedstawił konkretne przykłady "szczątkowej" obecności Józefa w niektórych celebracjach, przypomniał cel liturgii, jakim jest aktualizacja (czynienie aktualnym tego, co wydarzyło się 2000 lat temu) zbawczego życia Jezusa. Niektóre celebracje liturgiczne uobecniające na sposób sakramentalny tajemnice zbawcze Jezusa, dotyczą również św. Józefa. W nich powinniśmy znaleźć przestrzeń do mówienia o Świętym Józefie w sposób teologiczny, prawdziwy i zasadny. Podobnie jest $\mathrm{z}$ Maryją Panną: w liturgii nie ma oddzielnego cyklu maryjnego, ponieważ była ona "tylko" człowiekiem. Mówimy o niej zawsze i wspominamy w kontekście związku z tajemnicą osoby Chrystusa, Jego czynów i słów. Podobnie powinno być ze św. Józefem, niestety, widać wyraźną dysproporcję w zestawieniu z kultem maryjnym, zwłaszcza w dwóch księgach liturgicznych: Mszale, księdze ołtarza i Liturgii godzin. Ksiądz Konecki podkreślił, że zachowując wszelkie właściwe i konieczne proporcje musimy uczciwie powiedzieć, że kult św. Józefa zarówno w wymiarze historycznym, jak i współczesnym jest ciągle niedostateczny. 
Ksiądz Profesor przypomniał, że wielkość świętych mierzy się ich bliskością wobec Chrystusa, a Święty Józef po Matce Bożej był najbliższy Chrystusowi. Dzielił z Nim codzienne życie nie tylko w okresie dzieciństwa Jezusa, ale przez pełne trzydzieści lat, a jak pamiętamy w tradycji żydowskiej dziewczynki były wychowywane przez matkę, chłopcy natomiast przez ojca. Dopiero takie osadzenie św. Józefa w szerokim kontekście historii zbawienia pozwoli dostrzec jego wielkość i przekroczyć pewne stereotypy: $\mathrm{z}$ całym szacunkiem dla wszystkich zawodów i prac wykonywanych fizycznie, czy w sposób ręczny - wyjaśniał Prelegent, ale św. Józef jest przede wszystkim patronem profesorów i wychowawców, ponieważ wychował samego Syna Bożego.

Prelegent zaproponował dwa przykłady na potwierdzenie swojej tezy o nieobecnej obecności Józefa w liturgii: pierwszym jest święto Ofiarowania Pańskiego celebrowane w kalendarzu liturgicznym 2 lutego, którego formularz mszalny wcale nie wspomina o ważnej i pożądanej obecności św. Józefa, chociaż jest czymś oczywistym, że w tym wydarzeniu uczestniczył. Józef nie jest wspomniany ani w kolekcie, ani $\mathrm{w}$ prefacji. Natomiast $\mathrm{w}$ tekstach Liturgii godzin przeznaczonych na święto Ofiarowania Pańskiego Święty Józef jest wspominany zaledwie w dwóch miejscach, a konkretnie antyfonach w pierwszych i drugich Nieszporach. Widać więc, że św. Józef występuje w liturgii święta Ofiarowania Pańskiego w formie szczątkowej i ks. Konecki zaproponował większe zaakcentowanie osoby św. Józefa poprzez komentarz, homilię i modlitwę powszechną.

Jeszcze bardziej wyrazistym przykładem nieobecności Józefa w liturgii jest czas Adwentu. Przyglądając się tekstom liturgicznym, odnosi się wrażenie, że oczekujemy na przyjście Jezusa wyłącznie z Maryją, bez Świętego Józefa. Formularze mszalne tego okresu nie wymieniają w ogóle św. Józefa. W całym mszale rzymskim okresu Adwentu nie pada ani raz słowo "Józef". Ks. Konecki podkreślił, że taka sytuacja jest bardzo niesprawiedliwa i nieprawdziwa. Zaledwie troszkę lepiej jest w Liturgii godzin, której szczegółowa analiza pozwala stwierdzić, że Święty Józef wspominany jest $\mathrm{w}$ czterech miejscach.

Na zakończenie ksiądz Konecki przypomniał, że podczas Soboru Watykańskiego II wielu Ojców postulowało, aby św. Józefa ze względu na jego bliskość, udział i szczególne zasługi w misterium Chrystusa i Kościoła, niejako „odłączyć” od głównego „peletonu” Świętych, wyłączyć z grona pozostałych świętych, postawić go wyżej, nadać mu wyższy kult oraz zjednoczyć z Maryją, z którą tworzą faktyczny związek małżeński. 
Ten postulat jest ciągle aktualny, aby obecność Józefa była mniej nieobecna - zaznaczył ksiądz profesor Konecki.

Po trzech dniach wypełnionych prelekcjami, kolejny dzień Międzynarodowego Kongresu Józefologicznego został przeznaczony na odpoczynek: organizatorzy zorganizowali wycieczkę do Guadalajary. Licząca cztery i pół miliona mieszkańców Guadalajara jest jednym z największych miast Meksyku (drugim pod względem populacji). Uczestnicy Kongresu rozpoczęli zwiedzanie od świątyni św. Józefa, najstarszej w Guadalajarze, prowadzonej przez ojców józefitów, gdzie sprawowana była również Eucharystia. Kolejnym etapem było słynne Hospicio Cabanas, gdzie niegdyś mieścił się Dom Miłosierdzia, a dzisiaj znajduje się Instytut Kultury znany przede wszystkim z 57 fresków Josč Clemente Orosco, artysty zwanego przez niektórych meksykańskim Michałem Aniołem. Jego malarstwo może budzić różne odczucia, ale na pewno warto było zobaczyć jego wizję m.in. ewangelizacji i konkwisty, a także eksperymenty z perspektywą. Oprócz Hospicio Cabanas uczestnicy mogli zobaczyć również katedrę zbudowaną w 1561 roku, słynne Gazebo na Placu Broni, czy Pałac Gubernatora. Po południu złożono wizytę w Zapopan ze słynnym sanktuarium Matki Bożej czczonej tam w niewielkiej, bo mierzącej zaledwie $35 \mathrm{~cm}$ figurce.

\section{ŚWIĘTY JÓZEF W TEOLOGIl, LITERATURZE I KINIE}

W szóstym dniu Kongresu w porannej sesji wystąpiła siostra Dolores Siuta CSSJ, która mówiła o grupach modlitwy Świętego Józefa, jako jednej z form nowej ewangelizacji. My jednak zajmiemy się szerzej innym referatem, który został odczytany pod nieobecność autora. Chodzi bowiem o nestora światowej józefologii ojca profesora Tarcisio Stramare, który przypomniał, na czym powinna się oprzeć teologia rodziny w naszych czasach. Jego referat był zatytułowany: „Dwie Trójce, niebieska i ziemska, fundamentem teologii rodziny"

„Nie jest prawdą, jak się nieraz utrzymuje, że prawdy są tworzone w zależności od czasu i okoliczności, natomiast jest prawdą, że czas i okoliczności pomagają wyeksponować prawdy i promować ich rozwój" - napisał na początku o. Stramare i dobrze byłoby o tym pamiętać zawsze, kiedy rozmawiamy na temat nauczania Kościoła, dogmatów i generalnie prawd naszej wiary. Prawda, że Józef jest patronem Kościoła jest zapisana już w Ewangeliach, stwierdził Stramare, ale trzeba było czekać aż 
do trudnych czasów papieża Piusa IX, aby oficjalnie ją uznać i ogłosić. Dokładnie taki sam „los” spotkał prawdę o przynależności św. Józefa do tajemnicy Wcielenia, a także prawdę o roli Świętej Rodziny w tym misterium: dopiero dzisiaj, kiedy rodzina przechodzi turbulencje, jakie jej się nie zdarzyły nigdy wcześniej, zaczyna się brać „na poważnie” Świętą Rodzinę i przestaje traktować jako jedną z naiwnych pobożności.

W najważniejszym punkcie swoich rozważań ojciec Stramare stwierdza, że na pytanie, w czym na ziemi najlepiej odbija się rzeczywistość Trójcy Świętej, czyli Trzech Osób Boskich, odpowiedź znajdujemy w Rodzinie z Nazaretu, którą tworzą trzy osoby: Jezus, Maryja i Józef. Stramare przytacza wiele cytatów z różnych dzieł teologicznych na potwierdzenie tej tezy, w których wykazuje się podobieństwa i relacje, jakie zachodzą pomiędzy Trójcą Świętą i Rodziną z Nazaretu. Na przykład jezuita Pedro de Morales w XVII wieku porównywał Matkę Bożą do Boga Ojca, Jezus oczywiście jest tą samą osobą w obu Trójcach, natomiast św. Józefowi przypadła rola Ducha Świętego. Chociaż, gdy chodzi o św. Józefa, de Morales, dostrzegał w nim podobieństwo do wszystkich Osób Boskich: „Od Przedwiecznego Ojca ma imię, zadania i miejsce; dla Wcielonego Słowa jest prawdziwym ojcem we wszystkim, prócz naturalnego poczęcia, jest żywicielem i obrońcą; jest podobny do Ducha Świętego będąc prawdziwym mężem Maryi uważanej za oblubienicę Ducha Świętego, jest jej wiernym opiekunem". Te wszystkie cechy św. Józefa są znakomitą pomocą i wskazówką do codziennego życia wiarą i umacniania duchowości trynitarnej w każdym z nas i rzeczywiście na przestrzeni wieków liczne stowarzyszenia i osoby wybierały ten rodzaj duchowości potwierdzając i manifestując $w$ ten sposób wspomniany na samym początku zmysł wiary.

Stramare uznał za oczywiste, że w odkrywaniu ścisłej relacji pomiędzy dwiema Trójcami zawsze obecnej w wierzeniach ludu Bożego i na przestrzeni wieków dostrzeganej również w teologii, na początku było spojrzenie „z dołu do góry”, czyli od widzialnego do niewidzialnego: od ziemskiej trójcy ku Trójcy Świętej. I ponownie podjął Stramare poruszony wcześniej wątek, a mianowicie przyporządkowanie poszczególnych osób w obu Trójcach. Podczas gdy nie ma żadnego problemu z Jezusem, który jest centrum i racją połączenia Trójcy niebieskiej z trójcą ziemską, nie jest tak łatwo przyporządkować Józefa i Maryję. I tak, Charles de Saint-Paul na początku XVII wieku, choć dostrzega podobieństwo roli św. Józefa do Boga Ojca uważa, że Cieśla z Nazaretu jest obrazem Ducha Świętego. I można powiedzieć, że właśnie takie zdanie przeważa u większości 
teologów: Józef odzwierciedla Ducha Świętego, a Maryja jest „ustawiana” w pobliżu Boga Ojca. Ale, uwaga, tak dzieje się, kiedy wyraźnie tematem dyskusji, czy traktatu jest relacja pomiędzy dwiema Trójcami. Natomiast poza tym kontekstem bardzo często nazywa się Józefa "cieniem Ojca”. Jednak Stramare, choć uważa to wyrażenie za bardzo popularne i wręcz pociągające, twierdzi, że teologicznie nie posiada ono tego samego ciężaru gatunkowego jak porównania do Ducha Świętego. Dlaczego?

Przedstawianie Józefa jako „cienia Ojca” stało się popularne w XIX wieku i, jak twierdzi Stramare, nie pojawiło się nigdy jako sformułowanie w literaturze patrystycznej. Na czym ma polegać bycie cieniem Ojca? pyta Stramare. Kto jest podmiotem: cień czy Ojciec? Czy chodzi o to, że Ojciec rzuca cień, czyli Józefa, co byłoby jedynie prostym zasygnalizowaniem jego obecności, Ojciec działa, a cień jest prostą konsekwencją. Czy może chodzi o to, że cień ma swoją ważną rolę, przytłacza, zakrywa, staje na pierwszym planie? Bo jeśli mamy na myśli to drugie znaczenie, podkreśla Stramare, to i owszem, w literaturze patrystycznej obecność św. Józefa w tajemnicy Wcielenia ma taki właśnie charakter. Aktywny. Przez swoje małżeństwo z Maryją i w konsekwencji przypisywane mu ojcostwo Jezusa, św. Józef miał za zadanie "okrycie welonem” całego misterium Wcielenia. Właśnie, używa się nie tyle słowa „cien", ile „welon”. W tym kontekście można przytoczyć słowa kapucyna Louis'a-Francois'a d'Argentan'a z XVII wieku: „Stwierdzenie, że św. Józef jest obrazem Boga Ojca, jest przesadą, bo należy się ono jedynie Synowi Bożemu. Ale wyrażenie, że jest on cieniem Boga Ojca dobrze oddaje jego rolę, to jemu się należy, na tym polega jego chwała, jego przywilej i jego szczególny charakter". Bóg go stworzył jako szczególnego, jedynego w swoim rodzaju Świętego, „,aby był cieniem boskości, „ukrywając chwałę Boga, kiedy jeszcze było za wcześnie aby objawiła się światu".

Choć ojciec Stramare zajął się sformułowaniem „cień ojca” jedynie na marginesie swojej prelekcji, warto było je zrelacjonować, ponieważ kolejny referat tego dnia, który chcemy bliżej przedstawić nosi tytuł: „Cień ojca. Historia Józefa z Nazaretu w ujęciu Jana Dobraczyńskiego - studium literacko-teologiczne". Rzecz ciekawa, autorem tej prelekcji nie był Polak, a Hiszpan, konkretnie ks. Ignacio Soler od lat pracujący w prałaturze Opus Dei w Warszawie.

Ks. Soler rozpoczął swoje przedłożenie od konstatacji, z którą trudno się nie zgodzić: w obliczu wyzwania nowej ewangelizacji i pytań o skuteczniejsze głoszenie słowa Bożego zdajemy sobie sprawę, jak bardzo ważne od samego początku były i są media. Najpierw przekaz ustny 
na ulicach i w synagogach, próby mediacji za pomocą kultury i sztuki już od czasów św. Pawła i Areopagu, później przekaz pisemny i wreszcie środki masowej komunikacji w naszych czasach. Faktem jest również, że zwłaszcza dla ludzi młodych najważniejszym nośnikiem kultury stała się muzyka, której z kolei pierwszym źródłem stał się internet. Ksiądz Soler, który sam jest bardzo aktywnym uczestnikiem życia wirtualnego, uważa że literatura i kino pozostają fundamentalnymi środkami szerzenia kultury i ewangelizacji. I właśnie dlatego podczas kongresu postanowił zaproponować z jednej strony swoją interpretację dobrej książki autorstwa Jana Dobraczyńskiego, a z drugiej oparty na niej scenariusz filmu, którego głównym bohaterem byłby Święty Patriarcha.

Dla hiszpańskiego kapłana od lat zanurzonego w polską rzeczywistość trzy motywy jawią się jako decydujące w wyborze powieści Jana Dobraczyńskiego. Pierwszy jest osobisty. Ks. Soler z wielką przyjemnością wspominał, jak pierwszy raz czytał tę powieść w języku kastylijskim pod koniec lat siedemdziesiątych i był nią zachwycony. To wrażenie znalazło swoje potwierdzenie podczas kolejnej lektury, dwadzieścia lat później, tym razem w oryginale, czyli po polsku. Drugim motywem wyboru tej właśnie pozycji jest fakt, że przez wiele lat, zarówno w Hiszpanii, jak i w Polsce, różne osoby doradzały mu tę właśnie powieść jako znakomitą "lekturę duchową" i praktycznie wszyscy, którzy ją przeczytali mieli podobne do niego odczucia: nie był więc odosobniony w docenianiu walorów opowieści o św. Józefie. I wreszcie trzeci motyw: niewątpliwe walory samego Jana Dobraczyńskiego, który w swoich powieściach demonstruje wybitny talent pisarski, a jego dzieła charakteryzują się wysoką jakością artystyczną i teologiczną.

Nie mamy tutaj miejsca, aby opisywać fabułę książki polskiego pisarza, autora ponad 70 powieści, ale dla Solera obraz Józefa przedstawiony przez Dobraczyńskiego jest teologicznym majstersztykiem: uświęcenie przez pracę polega na przekształceniu jej w modlitwę, radosną służbę Bogu i bliźniemu. Taki Święty Józef, który kocha swoją żonę Miriam i chroni niczym cień swojego przybranego Syna Jezusa, z królem Herodem, który jest uosobieniem zła i nadaje dramatyzmu całej narracji, jest fantastycznym materiałem na dobry, ewangelizacyjny film.

Soler nabrał przekonania, że jest potrzebny dobry film, dzisiaj powiedzielibyśmy, kino familijne o św. Józefie, w którym będzie przedstawiony świat semicki i chrześcijański, ich wzajemne zależności i relacje. No i oczywiście taki film propagowałby Świętego Józefa - wzór małżonka i ojca, choć byłby skoncentrowany na Rodzinie z Nazaretu, przedstawiając 
świadectwo radosnej, pokornej pracy i jedności w rodzinie. Soler marzy o filmie na miarę „Pasji” Mela Gibsona, to znaczy dziele zrobionym z rozmachem i przez najlepszych, gdzie św. Józef byłby przedstawiony jako osoba radosna i zrealizowana w swoim człowieczeństwie poprzez obecność Jezusa i Maryi. „Nie chcę zrobić dramatu, ale radosne kino familijne, bo takie były lata Józefa, Jezusa i Maryi w Nazarecie" - stwierdził Soler. Jego marzeniem jest zainteresowanie scenariuszem samego Stevena Spieleberga, który nie tylko dał się poznać jako świetny reżyser i producent, ale w swoich filmach, podobnie jak Clint Eastwood, choć w zupełnie inny sposób, wydaje się szukać tego co transcendentne, czyli tego, co wykracza poza sprawy czysto ludzkie i naturalne. Czas najwyższy, stwierdził ks. Ignacio Soler, aby wielki reżyser zrobił przebój kinowy, w którym świat żydowski spotyka się z chrześcijańskim w wielkim, wzajemnym szacunku.

\section{ŚWIĘTY JÓZEF W MEDIACH}

Podobnie jak w pierwszym dniu obrad Kalisz i sanktuarium św. Józefa zaistniał na forum nie tylko w osobie prelegenta ks. dra hab. Dariusza Kwiatkowskiego, ale także w treści jego przedłożenia, tak też na zakończenie obrad meksykańskiego kongresu ponownie pojawiło się kaliskie sanktuarium, a także Dwutygodnik Diecezji Kaliskiej „Opiekun” w referacie zatytułowanym "Święty Józef jako wielki obrońca i troskliwy opiekun życia. Propagowanie kultu za pośrednictwem środków społecznego przekazu na przykładzie Dwutygodnika Diecezji Kaliskiej OPIEKUN" przedstawionym przez niżej podpisanego.

Jak przypomniał prelegent, istniejące od ponad piętnastu lat pismo zostało powołane do życia, aby zgodnie z wolą jego twórcy biskupa Stanisława Napierały „pomnożyć cześć św. Józefa. Powołując pismo, chcemy poniekąd wypełnić lukę polegającą na tym, że wielki Patron, św. Józef, nie ma w kraju pisma, które byłoby Mu poświęcone. Chcemy wypełnić drugą jeszcze lukę, mianowicie lukę w życiu naszej diecezji, która dotąd nie ma swojego pisma". Już od pierwszego numeru i jego zawartości dało się zauważyć, że jedną z głównych i ciągle obecnych form szerzenia kultu św. Józefa jest towarzyszenie wszelkim uroczystościom, pielgrzymkom i wydarzeniom odbywającym się w kaliskiej bazylice. Na łamach „Opiekuna” zawsze można znaleźć najpierw zaproszenia, a później sprawozdania, reportaże i fotorelacje dotyczące życia sanktuarium. 
Nawet w czasach, kiedy opadł pierwszy entuzjazm i wydawało się, że coraz trudniej o nowe materiały dotyczące Świętego i początkowe cztery strony dedykowane św. Józefowi zredukowano do dwóch, a później do zaledwie jednej strony, zawsze obecne były materiały z Bazyliki.

Istotnym wydarzeniem $\mathrm{w}$ kalendarzu kaliskiego sanktuarium stały się comiesięczne spotkania modlitewne w obronie poczętego życia i rodziny w pierwszy czwartek każdego miesiąca, które rozpoczęły się 3 czerwca 2004 roku i trwają po dziś dzień, a więc było ich już ponad 100. Są one wypełnieniem duchowego testamentu Jana Pawła II, który wezwał właśnie w Kaliszu do szczególnej troski o życie. Spotkania te zawsze były anonsowane na łamach pisma, ale począwszy od roku 2008 w Opiekunie pojawiają się bardzo szczegółowe sprawozdania z tych spotkań, często z fragmentami wygłoszonych konferencji czy homilii zaproszonych biskupów, a przy okazji pielgrzymki Rodziny Radia Maryja - fotoreportaże. To właśnie z tekstów będących pokłosiem tych spotkań najbardziej wyłania się św. Józef jako obrońca życia.

Autor prelekcji podkreślił również, że na łamach kaliskiego dwutygodnika pojawiają się regularnie materiały dotyczące artystycznych i teologicznych walorów różnych przedstawień Świętego Józefa, których zakres wykracza poza wizerunek kaliski i granice Polski. Szczególną część w spuściźnie „Opiekuna” stanowią materiały dotyczące teologii i duchowości św. Józefa. W roku 2008, na rok przed X Międzynarodowym Kongresem Józefologicznym w Kaliszu, redakcja podjęła starania, aby wrócić do treści pogłębionych, szukając jednocześnie sposobu ich przekazu łatwego do przyjęcia i zrozumiałego dla większości czytelników. W ramach tej linii redakcyjnej podjęto decyzję o zamieszczeniu na łamach niemal wszystkich referatów kongresowych, jednakże nie poprzez publikację integralnych tekstów wystąpień, ale raczej rozmów z ich autorami bądź omówień napisanych przystępnym językiem. Od tego czasu wszystkie referaty, również te wygłaszane podczas dorocznych krajowych sympozjów, znajdują na łamach gazety swoje popularyzatorskie omówienie. Choć największą część józefologii propagowanej na łamach „Opiekuna” zajmuje św. Józef w swej roli patrona ochrony życia nienarodzonych, to jednak nie brakuje również regularnych rubryk józefologicznych dla młodzieży i dzieci. Autor prelekcji przypomniał również, że w ramach serii wydawniczej Biblioteka "Opiekuna” ukazało się sześć monografii poświęconych św. Cieśli z Nazaretu.

Tak więc, choć proponowanie treści teologicznych jest poważnym wyzwaniem, aby z jednej strony nie zostały one przez czytelników po- 
minięte ze względu na zbyt hermetyczny język, a z drugiej strony, aby się nie dyspensować od ich publikacji i ustrzec od banalizacji, należy zauważyć, że przez piętnaście lat istnienia kaliski dwutygodnik z sukcesem poszerza cześć św. Józefa jako troskliwego obrońcy życia, co potwierdza jego systematycznie rosnący nakład.

\section{ZAKOŃCZENIE KONGRESU}

Ostatni dzień miał w programie zaledwie dwa punkty, jednakże okazały się one bardzo bogate $\mathrm{w}$ treść. Po południu w sanktuarium odbyła się "detronizacja” figur Maryi i św. Józefa z Dzieciątkiem, którym nałożono oryginalne, złote papieskie korony (na co dzień używane są kopie) i przygotowano w ten sposób do procesji. Wielka procesja, w której wzięło udział kilka tysięcy tancerzy i kilkadziesiąt tysięcy uczestników rozpoczęła się w seminarium, a zakończyła w katedrze, gdzie odbyła się również uroczysta Eucharystia na zamknięcie kongresu, której przewodniczył Nuncjusz Apostolski.

Wiemy już, że kolejny XII Międzynarodowy Kongres Józefologiczny odbędzie się we Francji, a Meksykanie przez swoją niesamowitą gościnność i nabożeństwo do św. Józefa postawili Francuzom poprzeczkę bardzo wysoko.

Wszystkie konferencje w kolejności wygłoszenia:

Mons. Roberto Octavio Balmori Cinta, MJ, Patrocinio de san José sobre los obispos.

Albert Perier, Chemin et cheminements de sainteté avec saint Josepph - Meditation sur saint Joseph ŕ l'aide de la statuaire.

Ryszard Dyc, Josef in den Schriften von hl. Edith Stein.

Joaquěn Ferrer Arellano, OCD, El matrimonio de Marěa y José, padre virginal y mesirnico de Cristo, a la luz de la mariologěa del beato Juan Duns Escoto.

José Luis Huerta, San José de Zapotlŕn, custodio de la vida digna.

Dariusz Kwiatkowski, San Giuseppe custode delle famiglie e il patrono della vita concepita nell'insegnamento di Stanislao Napierata - primo vescovo della Diocesi di Kalisz.

Stefania Colafranceschi, San Giuseppe, nutritor Domini: esempi di iconografia in Italia. Salvador Osnaya Velŕzques, MJ, San José, llama de amor ardiente, en el p. Vilaseca. Ambrosio García Moreno, MJ, El amor humano de María y José.

Angelo Catapano, La paternitŕ educativa. San Giuseppe custode della vita e dell'amore. Guglielmo Spirito OFM Conv., Saint Joseph of Montréal, a father for a fatherless society. 
Sandra de Arriba Cantero, José y Jesús. Iconografía de la relación del hijo con el padre.

Andrzej Latoń, San José - Testigo del misterio de Vida y Amor. Reflexiones filosóficoteológicas

Carolyn C. Wilson, An Augustinian Antiphonary from Lecceto and Aspects of the Loving Saint Joseph in Italian Renaissance Art.

Mons. Hermenegildo Ramírez Sánchez, MJ, Apuntes exegéticos y teológicos sobre san José y su custodia de la vida y el amor.

Joseph-Marie Verlinde, Saint Joseph, gardien (du sens) de la vie.

Miguel Piscopo D'Ambrosio, OSJ, San José custodio de la vida y del amor.

Krzysztof Konecki, Assente presenza di San Giuseppe nella liturgia di oggi.

Larry Toschi, OSJ, El Rosario de los Santos Esposos, mejor modo de divulgar popularmente una josefologěa cristocéntrica.

Alejandro Emmanuel Daza Estrada, MJ, Rasgos de una pastoral desde Nazaret. Jesůs que vivio con Marěa y José.

Francisco Brandle, OCD, San José, contemplado desde la fe que justifica.

Luis Rodrěguez Martěnez, OCD, Custodio de la Virginidad de Marěa.

Gilles de Christen, San José, patrono de la vida en al amor.

Germín Rovira Tarazona, La fe de san José.

Miguel Ángel Aguilar Manríquez, MJ, Porque aún no era justo, decidió repudiarla en secreto: nueva lectura de la justicia de san José.

Dolores Siuta CSSJ, Les groupes de pričre de Saint Joseph - une réponse au défi de la nouvelle évangélisation.

Román Llamas, OCD, San José, ministro de la salvación.

Carlos Saravia Maynez, San José, custodio de la nueva alianza.

Luis Javier Fernández Frontela, OCD, San José con el nińo Jesús, expresión de amor y ternura.

Tarcisio Stramare, OSJ, Le due Trinita, celeste e terrestre, fondamento della teologia della famiglia.

Ignacio Soler, La sombra del Padre. Historia de José de Nazaret de Jan Dobraczyński estudio literario y teológico. Propuesta de un guión.

Alberto Antonio Santiago, OSJ, San Giuseppe nel poema De Beata Virgine Maria del beato José de Ancheta (sec. XVI).

Gabriel Rodriguez Celis, MJ, San José, representante de Dios en la Tierra.

Annarosa Dordoni, San Giuseppe, padre, educatore e capo della Sacra Famiglia nell'etŕ tridentina e post-tridentina (secoli XVI-XVII).

Andrzej Klimek, San Giuseppe come „un grande difensore e premuroso protettore della vita". Divulgazione del culto attraverso i mezzi della comunicazione sociale sull'esempio de "Il Custode" - bisettimanale della diocesi di Kalisz.

Leopoldo Baez Ornelas, MJ, Alejandro Enrěquez Islas, MJ, San José y la juventud. José de Jesůs Marěa, ocd., Los celos de san José en el teatro barocco.

M. Daniel Picot, Une parole de saint Joseph pour lëhumanité jusqu'ŕ la fin des temps. Vincenzo Giampaolo, Il banchetto di san Giuseppe in Sicilia.

Alfredo Monreal Sotelo, San José de Zapotlín custodia la vida ante los terremotos. 